\title{
Caupolicán, en el modernismo de Darío
}

Es ya innegable que el interés de Rubén Darío por los temas americanos se mantiene latente a lo largo de su magistral producción ya que brota entusiasta y espontáneo en su estro poético con una regularidad que inclina a creer que esta afición era parte vital de su sensibilidad. ${ }^{1}$ No extraña, por lo tanto, que en los años de su iniciación poética se presentara sin titubear a un concurso literario cantando a las glorias de Chile, ${ }^{2}$ ni que en los años de plena madurez se dejara absorber por la preocupación del pasado y el porvenir de América en poemas de tan variada índole como "Salutación al Aguila", "A Roosevelt" y "Salutación del optimista", para mencionar sólo los más conocidos. Si se recuerda esta constante temática de Darío, no resulta insólita la presencia de composiciones de contenido americanista en $A z u l$, la obra en que menos podían esperarse, dado que lo distintivo de ella, al decir de don Juan Valera, es el "galicismo mental" 3 del autor. En efecto, se destaca señera en esta colección, la figura del indio Caupolicán, símbolo de gloria y encarnación de virtudes heroicas para los araucanos de ayer y para los lectores de hoy.

El tema; la fisonomía, el carácter y la individualidad toda del aborigen, así como las alternativas del torneo en que se empeña, no poseen novedad alguna, puesto que don Alonso de Ercilla y Zúñiga había relatado la prueba con minuciosidad y explotado hasta los más mínimos detalles los diversos aspectos físicos y las virtudes del guerrero nativo, al presentárnoslo en el Canto il de La Araucana. ${ }^{4}$ Lo nuevo y singular de la composición de Darío es el tratamiento mo- 
derno de un contenido que, por su vejez, parecía condenado a permanecer en estado de clásico.

En el soneto aludido, llama la atención, en primer lugar, el poder de síntesis del vate nicaragüense ya que en el reducido espacio que le proporcionaban los versos de un soneto, encuadró cada una y todas las cualidades y rasgos físicos de Caupolicán, así como también las alternativas de la prueba. Para llevar a cabo igual propósito, el genio español necesitó más de quince estrofas, con un total que sobrepasa los ciento veinte versos. E1 detalle, para el lector moderno, innecesariamente abundante y explícito en Ercilla, lo comunica Darío a base de sugerencias implícitas o por medio de breves descripciones estilizadas, que tienden a eliminar la monotonía de las interminables octavas reales, a la vez que a producir el efecto de rapidez o de lentitud, según lo requieran las circunstancias, siempre reteniendo un halo de estimulante sucesión. Es verdad que a Ercilla se le reserva la prioridad creativa, pero tampoco deja de ser cierto que Darío es el maestro de un nuevo modo de tratar con original efectismo ese contenido que al español se le transformó en pesada carga, cuando no en lastre.

Ejemplo de la excesiva palabrería de Ercilla son los versos

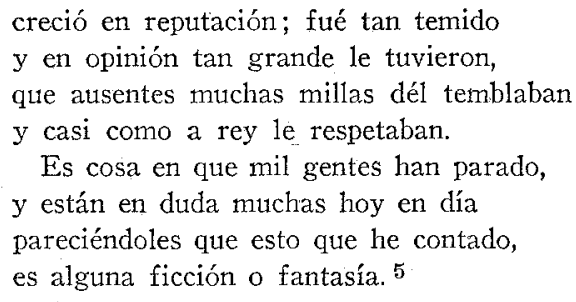

Darío expresa el concepto clave de los versos anteriores con una concisión más a tono con el propósito estético que abrigaba y que analizaremos más adelante, "Es algo formidable que vió la vieja raza".

Los detalles superfluos de Ercilla, tales como el episodio del madero traido con gran rapidez, o la repetición poco halagadora para las facultades imaginativas del lector actual, como aquello de explicar que el líbano con dificultad se rodeaba, en circunstancias en que ya se había insistido en su solidez y peso, todo ello, Datío lo 
reduce a unas cuatro palabras tan expresivamente descriptivas o más, que los versos del español.

Mientras Ercilla y Zúñiga canta con emocionada admiración,

Pues el madero de súbito traído

no me atrevo a decir lo que pesaba:

era un macizo líbano fornido

que con dificultad se rodeaba

Darío sintetiza a base de sugerencias, "robusto tronco de árbol".

Al hacer la descripción del cacique araucano, Ercilla se detiene a consignar una infinidad de rasgos físicos y espirituales cuya autenticidad se ha puesto en tela de juicio, creyéndose más bien que el afán del poeta obedecía más a una moda de su tiempo que a la realidad por él retratada: ${ }^{6}$
tenía un ojo sin luz de nacimiento
como un fino granate colorado, pero lo que en la vista le faltaba
en la fuerza y esfuerzo le sobraba.
E'ra este noble mozo de alto hecho, varón de autoridad grave y severo, amigo de guardar todo derecho, áspero, riguroso y justiciero:
de cuerpo grande y relevado pecho:
hábil, diestro, fortísimo y ligero,
sabio, astuto, sagaz, determinado
$y$ en cosas de repente reportado.

Darío aprovecha de nuevo varios conceptos expresados por Ercilla simplificándolos o cubriéndolos con una túnica modernista que resulta más deslumbrante y creíble para el lector y la sensibilidad de su tiempo. El vate nicaragüense también nos dice que Caupolicán era "salvaje y aguerrido", pero en vez de contarnos prosaicamente y en monótona enumeración que su héroe era "áspero, justiciero, de cuerpo grande y relevado pecho, fortísimo", nos lo sugiere en un verso más sólido y compacto, "brazo de Hércules o brazo de Sansón”. La impresión poco placentera que por su aspecto físico produciría el cacique al observador corriente, Ercilla la comunica indicando que al araucano le faltaba un ojo de nacimiento, detalle éste último difícil de constatar e inútil en un retrato, en tanto que 
Darío produce idéntica impresión combinando la fiereza poco atrayente con el concepto de que ella era indispensable para las actividades bélicas en que, con seguridad, tenía que participar Caupolicán muy a menudo, por el hecho de ser cacique, "Por cascos sus cabellos, su pecho por coraza". La cansadora lista de virtudes que hemos hallado en Ercilla experimenta una prodigiosa transformación gracias al genio creador de Darío. De "ligero" sale "lancero de los bosques"; de "infatigable", "Nemrod que todo caza"; de "alto hecho" y "cuerpo grande", "irguióse la alta frente"; de "hábil, astuto, sagaz", etc., "del gran Caupolicán".

Las alternativas y circunstancias del torneo, minuciosamente enumeradas por Ercilla, son de nuevo reducidas a un justo límite de buen gusto por Darío, quien además las reviste y retoca, según las exigencias de su propio arte, eliminando lo superfluo y reteniendo sólo lo más significativo y sugerente de su colorido.

Ercilla narra:

El bárbaro sagaz despacio andaba:

y a toda prisa entraba el claro día;

el sol las largas sombras acortaba;

mas él nunca decrece en su porfía.

Al ocaso la luz se retiraba;

ni por eso flaqueza en él había;

las estrellas se muestran claramente;

$y$ no muestra cansancio aquel valiente.

Salió la clara luna a ver la fiesta del tenebroso albergue húmedo y frío, desocupando el campo y la floresta de un negro velo lóbrego y frío.

He aquí cómo Darío extrae lo esencial de los versos de Ercilla:

Anduvo, anduvo, anduvo. Le vió la luz del dia, le vió la tarđe pálida, le vió la noche fría.

Sigue Ercilla en su relato:

Y el bárbaro en el hombro la gran viga sin muestra de mudanza y pesadumbre, venciendo con esfuerzo la fatiga y creciendo la fuerza por costumbre. 
Darío continúa empleando la misma pauta poética:

y siempre el tronco de árbol a cuestas del titán.

Por último, Ercilla remata la narración de la prueba:

Era salido el sol cuando el enorme
peso de las espaldas despedía,
y un salto dió en lanzándole disforme,
mostrando que aún ánimo tenía:
el circunstante pueblo en voz conforme
pronunció la sentencia y le decía:
sobre tan firmes hombros descargamos
el peso y grande carga que tomamos.

Darío reconstruye el mismo episodio en los conocidos versos:

"iEl Toqui, el Toqui!" clama la conmovida casta.

Anduvo, anduvo, anduvo. La aurora dijo: "Basta"

e irguióse la alta frente del gran Caupolicán.

A lo ya señaladamente distintivo de la adaptación de Dario, cabría añadir no sólo la precisión y colorido del lenguaje, sino además la estructura, ordenación y matices tonales que diferencian en lo fundamental su creación como perteneciente a la época modernista.

Es evidente que el soneto proporciona un vívido retrato del héroe en una brillante gama de matices sensoriales, en especial de tipo visual, una sensación de perfecta monotonía propia del torneo mismo y una distribución magistralmente equilibrada de los tres elementos básicos que constituyen lo medular del soneto, a saber, Caupolicán mismo, la prueba a que se somete y las circunstancias ambientales en que ésta tiene lugar.

Los cuartetos proporcionan una descripción rápida, a la vez que completa, de las cualidades físicas de Caupolicán, en tanto que los tercetos relatan la prueba misma y el medio en que ella se desarrolla hasta culminar con la elección del toqui.

El primer verso estimula la curiosidad del lector porque el poeta, a modo de preludio, se limita a decir que se trata de "algo formidable" que vió la vieja raza, recurso que no tiene otro propósito que predisponer a la veloz descripción en hipertonos que se reserva 
para los siete versos siguientes de los dos cuartetos. La descripción se mueve con inusitada rapidez por la omisión sistemática del verbo en los versos dos y tres del primer cuarteto, y en el uno y tres del segundo, artificio estilístico que hace más sugerente que enumerativamente explícita al caracterización del héroe. A esta frecuente omisión del verbo, el poeta opone en los restantes versos de los cuartetos, y en especial en los tercetos, una cantidad abrumadora de ellos, acaso por ser indispensables para reproducir las acciones que el torneo involucra: cazar, estrangular, andar (tres veces seguidas), ver (tres veces), clamar, decir, bastar, erguirse, etc. Esta abundancia de los verbos suministra, además, el perfecto equilibrio lexicográfico que se observa entre los cuartetos y los tercetos: mientras en los primeros predominan sin contrapeso los adjetivos y los sustantivos por tratarse de un retrato en quietud, en los segundos, los numerosos versos se combinan en debida proporción con otras partes de la oración para, junto con hacer olvidar su intermitente ausencia en los versos iniciales del soneto, describir las diversas acciones del torneo.

Por su lógica, la ordenación de los episodios es también digna de admiración. En efecto, cuando la figura de Caupolicán ya se ha convertido en realidad tangible, Darío enumera las hazañas que este guerrero de la región de Arauco pudo haber realizado además de sostener el tronco. Esta enumeración tiene una doble función en el poema. Precisamente porque Caupolicán pudo haber sido lancero de los bosques, Nemrod que todo caza, y estrangulador o desjarretador de toros, se explica que pudiera sostener el tronco y tuviera las prendas para ser toqui. Del mismo modo, por su éxito en el torneo, cabe predecir inversamente igual tritinfo en otras difíciles pruebas. Así queda de paso solucionado aquel enigma del "algo formidable" que vió la vieja raza. Hay que recalcar, sin embargo, que este doble valor funcional de lo descriptivo y de lo enumerativo es algo totalmente desconocido en la obra de Ercilla.

La descripción de la prueba misma, que debió de ser monótona y aburridora, da la sensación de tal a causa de las repeticiones tan frecuentes e intencionales de los versos iniciales del primer terceto:

Anduvo, anduvo, anduvo. Le vió la luz del día. le vió la tarde pálida, le vió la noche fría. 
E1 tercer verso del primer terceto, aunque de mayor variedad lexicográfica, mantiene la tónica de los renglones iniciales de la estrofa ya que persiste la nota de uniformidad, si bien con menor intensidad. Comparemos, pues, la monótona lentitud del "Anduvo, anduvo, anduvo", etc., con la inmovilidad visual de "y siempre el tronco de árbol a cuestas del titán".

Paulatinamente se penetra en el ambiente del último terceto que posee tun ritmo tonal diferente. Los indios "conmovidos", es decir, impulsados emocionalmente, prorrumpen en "clamores" cuando la prueba ya toca a su fin. Mézclase de nuevo el ritmo lento del primer terceto, "Anduvo, anduvo, anduvo", a la algarabía de los aborígenes, en tanto que la aurora, personificación del justo medio, pone fin a la monotonía y, aparentemente, al vocerío para dejar que los acontecimientos sigan su curso normal.

Es de observar que la participación de la aurora debió de preceder cronológicamente a los clamores de la conmovida casta. Así lo comprendió y lo expresó Ercilla. Darío, no obstante, pone los hechos en sentido inverso, para dar la impresión, a todas luces equívoca, de que la aurora salió de su actitud de indiferencia al oír los clamores de los indios ante aquello "formidable". Darío no quiere que los aborígenes lancen los gritos después de pronunciado el fallo de la aurora ante lo formidable que se había presenciado. Esta última alternativa, de ser así incorporada por Darío, hubiera resultado de un prosaísmo insoportable y disonante.

E1 último verso del soneto reanuda la intensidad tonal del primero ya que el hecho formidable se vuelve a mencionar, si bien en términos diferentes: al comienzo de la composición en calidad de incógnita, por los motivos ya anotados, y al fin explícitamente para acentuar el contraste tonal, rítmicamente alternante y esquivo que corre por todo el poema.

En suma, aparte de las prendas muy modernistas que adornaban a la persona y a la conducta de Caupolicán, en especial sú carencia de medios modernos (cabellos por casco, pecho por coraza) y su triunfo a base de virtudes naturales, tales como fuerza y resistencia, todo lo cual convierte al toqui en un símbolo agigantado de las nuevas esperanzas poéticas de la joven generación, Darío ha aprovechado la vieja tradición arattcana, tan objetivamente explotada 
por Ercilla con espesos residuos renacentistas, para entregar una creación rica en propósitos estilísticos magistralmente realizados y de una novedad digna de la más sincera admiración.

\author{
Homero Castillo, \\ Northwestern University.
}

\title{
$\mathrm{N} O \mathrm{~T}$ A S
}

1 Arturo Torres-Rioseco, Rubén. Darío, casticismo y americanismo. (Cambridge, Massachusetts, Harvard University Press, 1931).

2 Ibid., p. 23.

3 Rubén Darío, Azul, "Carta-Prólogo de Juan Valera". (Buenos AiresMéxico, Espasa-Calpe Argentina, S. A., 1939), p. 31.

4 Alonso de Ercilla y Zúñiga, La Araucana. (Buenos Aires, Clásicos Americanos, Talleres Gráficos de Editorial Molino. Argentina, 1944.)

5 En las citas ilustrativas que siguen, hemos utilizado las ediciones de Azul y de La Araucana consignadas en las dos notas precedentes. E1 soneto que nos interesa en este trabajo dice así :

Es algo formidable que vió la vieja raza;

robusto tronco de árbol al hombro de un campeón salvaje y aguerrido, cuya fornida maza blandiera el brazo de Hércules o el brazo de Sansón. Por cascos sus cabellos, su pecho por coraza, pudiera tal guerrero, de Arauco en la región, lancero de los bosques, Nemrod que todo caza, desjarretar un toro, o estrangular un león. Anduvo, anduvo, anduvo. Le vió la luz del día, le vió la tarde pálida, le vió la noche fría, y siempre el tronco de árbol a cuestas del titán. " EI Toqui, el Toqui!", clama la conmovida casta. Anduvo, anduvo, anduvo. La aurora dijo: "Basta", e irguióse la alta frente del gran Caupolicán.

6 Bernard Moses, Spanish Colonial Literature in South America, 18101824. (New York, Hispanic Society, 1922), pp. 179-184. 